\title{
Peran Ukuran Perusahaan pada Determinan Voluntary Auditor Switching
}

Slamet Riyanto ${ }^{1}$, Syahril Djaddang², Suyanto ${ }^{3}$

DOI: https://doi.org/10.35838/jrap.2021.008.02.20

1 Universitas Pancasila, Jakarta Selatan, DKI Jakarta

2 Universitas Pancasila, Jakarta Selatan, DKI Jakarta

3 Sekolah Tinggi Ekonomi IPWIJA, Jawa Barat, Bekasi

\section{ARTICLE INFO \\ JEL Classification: M41; M42}

\section{Keywords:}

financial distress, management changes, public accounting firm's size, audit opinion, company's size

\begin{abstract}
This study aims to find the effect of Financial Distress, Management Change, KAP Size, Audit Opinion on Voluntary Auditor Switching, moderated by Company Size. The objects in this study are companies included in the manufacturing sector, which were listed on the Indonesia stock exchange during 2014-2018, with 95 companies. The sampling method used in this study was purposive sampling. The collected data were analyzed using descriptive analysis and statistical analysis techniques using the WarpPLS 5.0 program. The results showed that Financial Distress, Change of Management, Audit Opinion did not affect Voluntary Auditor Switching. At the same time, KAP Size, Company Size had a significant adverse effect on voluntary auditor switching. Company size was found to moderate the financial distress of Voluntary Auditor Switching and Management Change, homologize moderation, KAP size is the predictor moderation of Voluntary Auditor Switching. It is recommended for further research to increase the number of research samples, range of research times, and indicators of each variable.
\end{abstract}

\begin{abstract}
ABSTRAK
Penelitian ini bertujuan untuk mengetahui pengaruh Financial Distress, Pergantian Manajemen, Ukuran KAP, Opini Audit Terhadap Voluntary Auditor Switching dengan Moderasi Ukuran Perusahaan. Objek pada penelitian ini adalah perusahaan yang masuk dalam sektor manufaktur yang terdaftar pada bursa efek Indonesia selama tahun 2014-2018, dengan jumlah 95 perusahaan. Metode pengambilan sampel yang digunakan dalam penelitian ini adalah purposive sampling. Data yang terkumpul dianalisis dengan tehnik analisis deskriptif dan analisis statistik, dengan menggunakan program WarpPLS 5.0. hasil penelitian menunjukkan bahwa Financial Distress, Pergantian manajemen, opini audit tidak berpengaruh terhadap Voluntary Auditor Switching, sedangkan Ukuran KAP, Ukuran perusahaan berpengaruh negative signifikan terhadap voluntary auditor switching. Ukuran Perusahaan ditemukan sebagai mampu memoderasi financial distress Voluntary Auditor Switching dan Pergantian Manajemen, homologise moderation, Ukuran KAP predictor moderation terhadap Voluntary Auditor Switching. Disarankan untuk penelitian selanjutnya meningkatkan jumlah sampel penelitian, rentan waktu penelitian, dan indikator masing-masing variabel.
\end{abstract}

\section{PENDAHULUAN}

Perkembangan profesi akuntan publik dipengaruhi oleh pertumbuhan jumlah perusahaan. Semakin bertambah banyak jumlah perusahaan publik maupun non publik, akan semakin banyak pula dibutuhkan jasa akuntan publik. Kantor Akuntan Publik (KAP) dan Akuntan Publik (AP) akan bersaing ketat demi mendapatkan klien, sehingga akan berupaya keras memberikan jasa audit sebaik mungkin. Kondisi saat ini dimana jumlah KAP dan AP cukup banyak, menjadikan perusahaan leluasa untuk memilih apakah tetap menggunakan KAP dan AP yang sama atau melakukan pergantian KAP (Auditor switching).

Beberapa faktor dapat berpengaruh terhadap auditor switching, antara lain: opini audit, pergantian manajemen, ukuran KAP, dsb. Secara opini audit, klien tentu saja menginginkan laporan keuangannya mendapat opini tanpa modifikasi dari KAP, karena opini tanpa modifikasi atas laporan keuangan akan 
berpengaruh terhadap

pengambilan

keputusan. Sulistiarini dan Sudarsono dalam Saputri dan Achyani (2013) Faktor yang mempengaruhi auditor switching dari sisi klien yaitu, perusahaan yang mengalami kondisi financial distress sudah tidak memiliki kemampuan untuk membayar biaya audit yang dibebankan oleh KAP, sehingga perusahaan mengganti auditor dengan fee audit yang lebih murah.

Faktor lainnya yang mepengaruhi auditor switching yaitu, pergantian manajemen dalam sebuah perusahaan akan mempengaruhi terjadinya perubahan kebijakan dalam bidang akuntansi, keuangan dan pemilihan Kantor Akuntan Publik. Pergantian manajemen umumnya diikuti oleh pergantian KAP karena KAP dituntut untuk mengikuti kehendak manajemen, seperti kebijakan akuntansi yang dipakai oleh manajemen. Oleh sebab itu, seperti pendapat Rahayu (2014) manajemen memerlukan auditor yang lebih berkualitas dan mampu memenuhi tuntutan pertumbuhan perusahaan. Penelitian oleh Susan dan trisnawati (2011) berhasil membuktikan ada pengaruh akibat pergantian manajemen terhadap auditor penelitian yang switching. Sedangkan menyatakan bahwa pergantian manajemen tidak mempengaruhi perusahaan untuk berpindah KAP.

Reputasi auditor berperan serta dalam menentukan kredibilitas (kualitas, kapabilitas, kekuatan yang menimbulkan kepercayaan) atas laporan keuangan. Dalam penelitian ini KAP yang memiliki reputasi diproxykan dengan The Big 4. Penelitian Praptitorini dan Januarti (2007) dalam Saputri dan Achyani 2013) menyatakan bahwa investor cenderung lebih percaya pada laporan keuangan hasil audit yang dilakukan oleh auditor yang bereputasi. The Big 4 merupakan auditor dengan reputasi dan keahlian yang lebih baik daripada auditor selain The Big 4. Hasil penelitian tersebut bertolak belakang dengan penelitian Sinarwati (2010) yang mengatakan reputasi auditor tidak berpengaruh pada auditor switching.

Rumusan masalah dalam penelitian ini bertujuan untuk menguji dan menganalisa pengaruh financial distress, pergantian manajemen, ukuran KAP, opini audit, reputasi auditor, dengan menambahkan ukuran perusahaan untuk menguji kuat atau lemah pengaruhnya masing-masing secara parsial atau bersama-sama terhadap auditor switching.

\section{TELAAH \\ TEORI \\ PENGEMBANGAN HIPOTESIS}

DAN

Penelitian ini menggunakan pendekatan teori agensi untuk membahas hubungan antara pihak pemegang saham sebagai prinsipal dan pihak manajer sebagai agen dalam pemisahan antara kepemilikan dan pengendalian perusahaan, antara pemasok modal yang berbeda, dalam pemisahan penanggungan resiko, pembuatan keputusan dan fungsi pengendalian dalam perusahaan seperti yang dikemukakan oleh Jensen dan Meckeling dalam Saputri dan Achyani (2013).

Masalah yang kerapkali muncul dalam hubungan agensi adalah asimetri informasi. Terdapat dua jenis asimetri informasi, yaitu: adverse selection dan moral hazard seperti yang dijabarkan oleh Hendricksen dan Breda dalam Saputri dan Achyani (2013) adverse selection adalah suatu kondisi dimana beberapa pihak seperti: manajer, dan pihak pihak internal lainnya lebih mengetahui kondisi perusahaan, saat ini dan prospek ke depan perusahaan dibandingkan prinsipal. jika manajer bekerja dengan standar yang lebih baik daripada yang ditetapkan oleh prinsipal, maka prinsipal hanya akan menilai dengan standar umum yang diketahuinya saja, seperti pendapat Morris dalam Saputri dan Achyani (2013). Moral hazard adalah kondisi dimana para manajer lebih mengutamakan kepentingannya sendiri sehingga prinsipal tidak dapat mengamati seluruh aksi manajer yang dapat berbeda dengan apa yang diharapkan principal , seperti yang diungkapkan oleh Hendriksen dan Breda dalam Saputri dan Achyani (2013).

Para investor sebagai prinsipal secara khusus tidak ambil bagian dalam rangka operasi harian perusahaan, tetapi mereka melimpahkan tanggung jawab ini kepada manajemen yang berfungsi sebagai agen. Jika masing-masing pihak bertindak menurut kepentingannya 
sendiri, pemisahan ini menghasilkan konflik agensi. Solusi dapat ditempuh dengan melakukan perikatan dengan auditor eksternal untuk mengevaluasi kinerja manajer. Pada saat perusahaan memilih auditor eksternal, perusahaan akan mempertimbangkan kualitas auditor atau KAP dan kondisi intern perusahaan. Kualitas KAP berdampak pada persepsi pemakai laporan keuangan, dan biaya (fee audit) yang dikeluarkan perusahaan. Solusi lainnya adalah memberikan insentif kepada manajer, misalnya pemberian saham, agar kepentingan investor dan manajer sejalan.

Auditor Switching

Auditor switching, kerap kali dilakukan perusahaan dengan mengganti KAP atau auditor yang ada. Penggantian auditor dapat dilakukan dengan mandatory atau mandatory auditor switching dan voluntary. Menurut Nabila (2011), mandatory auditor switching dilakukan ketika terdapat mandat dari peraturan Beda halnya dengan mandatory, keputusan perusahaan untuk merotasi KAP secara voluntary, disebabkan adanya ketidaksesuaian antara tindakan yang dilakukan KAP sebelumnya dengan harapan manajemen perusahaan. (Wijayanti, 2010). Latar elakang keputusan penggantian KAP baik secara mandatory maupun voluntary ialah dipengaruhi sifat independensi yang harus dimiliki oleh auditor selama bertugas sehinggga semakin panjang tenure masatugas pada suatu klien maka independensi auditor bisa menjadi diragukan.

\subsection{Telaah Teori \\ Financial Distress}

Menurut Plat dalam Saputri dan Achyani (2013) inancial distress ditandai jika kondisi keuangan perusahaan sudah mencapai pada tahap penurunan yang biasa terjadi sebelum likuidasi atu kebangkrutan. Tahap penurunan di sini, cenderung mengarah pada defisitnya laba perusahaan sebagai akibat dari kegagalan operasional perusahaan dalam mencari laba sehingga terjadi kebangkrutan. Istilah lain dari kebangkrutan yaitu, likuidasi, penutupan perushaan, atau insolvensi. Selain itu, kebangkrutan juga sangat dekat kaitannya dengan kegagalan keuangan dan kegagalan ekonomi seperti pendapat Adnan dan Kurniasih dalam Saputri dan Achyani (2013).

\section{Pergantian Manajemen}

Pergantian manajemen erat kaitannya dengan timbulnya kebijakan baru sesuai dengan kehendak direktur utama yang baru. Dampak yang ditimbulkan dapat berpengaruh luas, sejalan dengan wewenang yang dimilki oleh direktur utama sebagai penanggungjawab pengambil keputusan, pemimpin, pengelola dan eksekutor pada kelangsungan perkembangan dan kemajuan perusahaan. Kebijakan baru ini ditujukan kepada manajemen baru untuk meningkatkan kualitas dan standar kualitas perusahaan selama masa jabatannya. Menurut Sinarwati (2010), pengambilalihan tersebut memberikan kesempatan kepada perusahaan klien untuk menunjuk auditor baru yang lebih berkualitas, lebih kolaboratif dan sejalan dengan kebijakan akuntansi dan pelaporan mereka.

\section{Ukuran KAP}

DeFond (1992) menyatakan bahwa kualitas audit juga dapat ditentukan oleh besar kecilnya perusahaan audit itu sendiri. KAP kecil memiliki sumber daya yang lebih terbatas, yang kemudian dianggap sebagai kualitas yang lebih rendah. Menurut Damayanti dalam Wijaya (2013), empat kategori pemilik KAP dirinci sebagai berikut:

a. Kantor Akuntan Publik Internasional

b. Kantor Akuntan Publik Nasional

c. Kantor Akuntan Publik Lokal dan Regional

d. Kantor Akuntan Publik Lokal Kecil

Ukuran KAP adalah Salah satu faktor yang menentukan rotasi Auditor terjadi karena ukuran KAP mencerminkan reputasi dan kualitas yang lebih baik. Besar kecilnya KAP juga menentukan kredibilitas auditor. KAP besar seringkali memiliki tingkat kredibilitas dan pengalaman yang tinggi.

\section{Opini Audit}

Opini audit merupakan pernyataan pendapat yang diberikan auditor independen dalam menilai kewajaran penyajian laporan 
keuangan perusahaan. Opini dari auditor independen menjadi sumber informasi penting untuk dipertimbangkan oleh para pemakai laporan keuangan. Manajemen menginginkan unqualified opinion atas laporan keuangannya. Sehingga apabila auditornya memberikan pendapat yang tidak sesuai keinginan, maka klien cenderung untuk memberhentikan auditornya seperti yang diungkapkan oleh Pawitri dan Yadnyana (2015).

Jenis-jenis pendapat Akuntan menurut SA 700 (IAPI, 700) dan SA 705 (IAPI, 705) yang berlaku untuk audit atas laporan keuangan tahun 2013, opini auditor dibagi menjadi dua:

a. Opini tanpa modifikasi (unmodified opinion) Opini tanpa modifikasi diberikan jika auditor menyimpulkan bahwa laporan keuangan telah disusun sesuai dengan standar akuntansi keuangan yang berlaku.

b. Opini dengan modifikasi (modified opinion) Opini dengan modifikasi diberikan jika auditor menyimpulkan bahwa laporan keuangan tidak bebas dari (mengandung) salah saji material.

\section{Ukuran Perusahaan}

Menurut Kurniaty (2014), ukuran perusahaan akan secara langsung mencerminkan naik turunnya kegiatan operasional perusahaan. Perusahaan besar umumnya lebih kompleks daripada perusahaan atau unit yang lebih kecil. Ukuran perusahaan juga berkaitan dengan total aset menurut BAPEPAM No. 11/PM/1997, yang menyatakan: "Perusahaan menengah atau kecil adalah perusahaan dengan total aset tidak lebih dari Rp100 miliar". Ukuran perusahaan dalam penelitian ini diukur dari total aset perusahaan.

\subsection{Pengembangan Hipotesis}

\section{Financial Distress Terhadap Voluntary Auditor Switching}

Menurut Plat (2002), kesulitan keuangan adalah masalah likuiditas yang sangat parah yang tidak bisa dipecahkan tanpa perubahan ukuran dari operasi atau struktur perusahaan
Pada penelitian Agiastuti dan Saputra (2012) menemukan bahwa semakin besar financial distress perusahaan semakin besar voluntary auditor switching dan sebaliknya semakin kecil financial distress semakin kecil pula voluntary auditor switching yang dilakukan oleh perusahaan. Hasil penelitian oleh HIdayati dan sari, dkk (2018) membuktikan bahwa kesulitan keuangan tidak menjadi faktor yang mendorong suatu perusahaan untuk berganti KAP.

Kesulitan keuangan diukur dengan Altman Z-score. Analisis kebangkrutan Z-score ditemukan oleh Edward I. Gamayuni (2011) mengemukakan bahwa altman yang bertujuan untuk memprediksi kebangkrutan perusahaan manufaktur yang Terdaftar di Bursa Efek Indonesia dengan menggunakan matrik keuangan dalam metodologi statistik multidiskriminan. Menurut Wibisono (2013), persamaan model kebangkrutan Z-score yang digunakan untuk menguji prakiraan kebangkrutan adalah hubungan antara rasio modal kerja terhadap total aset, laba ditahan terhadap total aset, laba sebelum bunga dan pajak terhadap total aset, rasio nilai buku ekuitas terhadap nilai buku dari utang dan penjualan terhadap total aset, dari ekuitas pemegang saham. nilai utang dan rasio penjualan terhadap total neraca. Pemeringkatan perusahaan yang sehat dan bangkrut berdasarkan nilai Z-score model Altman, yaitu:

a. Jika nilai $Z<1,23$ maka termasuk perusahaan yang bangkrut

b. Jika nilai $1,23<Z<2,9$ maka termasuk grey area (tidak dapat menentukan apakah perusahaan tersebut sehat atau pailit)

c. Jika nilai $Z>2,9$ maka termasuk perusahaan yang tidak pailit.

Berdasarkan pernyataan di atas hipotesis pertama dirumuskan sebagai berikut:

H1: Kesulitan keuangan mempengaruhi perubahan sukarela auditor.

\section{Pergantian Manajemen Terhadap Voluntary Auditor Switching \\ Perubahan arah tersebut} direpresentasikan dalam penelitian ini dengan pergantian CEO sebuah perusahaan. Fungsi utama CEO adalah sebagai pengambil 
keputusan, eksekutif, manajer dan eksekutif dalam memimpin dan mengelola perusahaan. Menurut Olivia dalam Lesmana (2016), tanggung jawab CEO sepertinya sulit karena dia memimpin perusahaan secara keseluruhan untuk kelangsungan hidup perusahaan sehingga dapat terus berkembang dan berkembang. Penelitian oleh Pawitri dan Yadnyana (2015) menunjukan bahwa pergantian manajemen berpengaruh positif signifikan terhadap voluntary auditor switching. Selain itu, Kurniaty (2015) berpendapat pergantian manajemen bukan faktor yang menyebabkan perusahaan melakukan auditor switching.

Perubahan kepengurusan baru, sebagian besar diikuti dengan pedoman baru di dalam perusahaan. Tentunya kebijakan baru tersebut dimaksudkan untuk membantu manajemen baru dalam meningkatkan kualitas dan standar mutu perusahaan di era kepemimpinannya. Menurut Sinarwati (2010), perubahan manajemen menawarkan kesempatan untuk menunjuk auditor baru yang lebih berkualitas, lebih kooperatif, dan sesuai dengan prinsip akuntansi dan pelaporan. Berdasarkan pernyataan sebelumnya, maka dirumuskan hipotesis kedua sebagai berikut:

H2: Perubahan manajemen mempengaruhi voluntary auditor switching.

\section{Ukuran KAP Terhadap Voluntary Auditor Switching}

Ukuran KAP dapat dibagi menjadi KAP yang terkait dengan Big 4 dan KAP yang tidak terkait dengan Big 4. Menurut Olivia (2014), investor lebih cenderung menggunakan laporan auditor independen dari auditor terakreditasi. KAP dari kelompok Big 4 KAP adalah: Pricewaterhouse Coopers, Deloitte Touche Tohmatsu, Ernst and Young dan KPMG Penelitian Pawitri dan Yadnyana (2015) membuktikan bahwa ukuran KAP berpengaruh signifikan terhadap voluntary auditor switching. Di sisi lain, Manta dan Manda (2014) menyatakan bahwa variabel ukuran KAP tidak berpengaruh terhadap auditor switching.

Pelaku bisnis akan mencari KAP dengan kredibilitas tinggi untuk meningkatkan kepercayaan laporan keuangan di mata pengguna laporan keuangan. Ketika suatu perusahaan telah menggunakan jasa Big 4, sedapat mungkin perusahaan tersebut akan tetap menggunakan jasa KAP yang termasuk dalam Big 4. Oleh karena itu, semakin besar ukuran KAP yang digunakan pada tahun sebelumnya maka semakin kecil kemungkinan perusahaan tersebut akan melakukan pergantian auditor seperti pendapat Wijayanti (2010). Berdasarkan pernyataan di atas, maka ditetapkan hipotesis sebagai berikut:

H3: Ukuran KAP berpengaruh terhadap pergantian sukarela auditor.

\section{Opini Audit Terhadap Voluntary Auditor Switching}

Opini audit adalah pernyataan atas suatu asersi yang dikeluarkan oleh auditor. Opini audit harus didasarkan atas pemeriksaan yang dilaksanakan sesuai Standar Pemeriksaan Akuntan Publik. Opini audit ada dua tipe, yaitu: tanpa modifikasi dan dengan modifikasi, tanpa modifikasi ada satu opini wajar, sedangkan opini modifikasian ada empat, yaitu, wajar dengan paragraf penjelas, wajar dengan pengecualian, pendapat tidak wajar, dan tidak menyatakan pendapat menurut SA 700 (IAPI, 700) dan SA 705 (IAPI, 705).

Dalam penelitian Nasir (2018), Widnyani dan Muliaartha (2018) dan Juliantari dan Rasmini (2013), menyatakan perusahaan yang menggunakan auditor baru akan menerima opini yang sama, atau opini yang tidak jauh berbeda dari opini yang diberikan auditor sebelumnya, karena auditor baru akan tetap melihat laporan auditor independen KAP sebelumnya.

Apabila auditor tidak memberikan opini sesuai dengan yang perusahaan harapkan, maka perusahaan cenderung mencari dan menggunakan KAP lain yang mungkin akan memberikan opini yang sesuai dengan harapan 
perusahaan. Menurut Wijayani (2011), hal tersebut disebabkan karena tidak ada perusahaan yang menginginkan opini qualified, munculnya opini tersebut akan menurunkan kredibilitas laporan keuangan perusahaan dimata para pemakai laporan keuangan. Berdasarkan pernyataan sebelumnya, hipotesis keempat ditetapkan sebagai berikut:

H4: Hubungan opini audit untuk tahun sebelumnya terkait dengan voluntary auditor switching.

\section{Ukuran Perusahaan Terhadap Voluntary Auditor Switching}

Jumlah keseluruhan aset yang dimiliki oleh suatu perusahaan dapat digunakan sebagai tolok ukur dari perusahaan tersebut. Semakin besar total aset sebuah perusahaan dapat menjadi indikasi seberapa besar perusahaan tersebut dan begitu juga sebaliknya (Citra dan Adi, 2011). Menurut Adeng dan Adi (2012), klien-klien yang memiliki jumlah keseluruhan aset kecil cenderung akan memilih KAP yang bukan bagian dari Big 4, sedangkan untuk perusahaan yang memiliki total keseluruhan aset besar tetap memilih KAP Big 4 sebagai auditornya yang mencerminkan adanya kesesuaian ukuran antara KAP dengan kliennya.

Dalam penelitian Kurniawan (2017), menunjukkan temuan bahwa ukuran perusahaan tidak dapat mempengaruhi perusahaan ketika mengganti auditor. Selain itu, hasil penelitian Kurniaty (2014) serta Wea dan Murdiawati (2014) menunjukan bahwa auditor switching dipengaruhi oleh ukuran perusahaan.

Menurut Mutchler dalam Saputri dan Achyani (2013), perusahaan besar dipercayai bisa menyelesaikan kesulitan-kesulitan keuangan yang dihadapinya daripada perusahaan kecil Seiring pertumbuhan ukuran perusahaan, akan membuat prinsipal semakin sulit dalam memonitor tindakan agen, yang kemungkinan cenderung memaksimalkan keuntungan pribadinya daripada keuntungan prinsipal. Berdasarkan pernyataan sebelumnya, hipotesis kelima ditetapkan sebagai berikut:
H5: Ukuran perusahaan mempengaruhi voluntary auditor switching.

Pengaruh Financial Distress Terhadap Voluntary Auditor Switching dengan Ukuran Perusahaan sebagai Variabel Moderasi, Pengaruh Pergantian Manajemen Terhadap Voluntary Auditor Switching dengan Ukuran Perusahaan sebagai Variabel Moderasi

Sesuai dengan penelitian Rusmini (2018), Kurniaty (2014), dan Pawitri (2015) tentang voluntary auditor switching menyimpulkan bahwa ukuran perusahaan berpengaruh terhadap voluntary auditor switching. Berdasarkan uraian tersebut diatas pengembangan hipotesis penelitian, berikut:

H6: Financial Distress Berpengaruh Terhadap Voluntary Auditor Switching dengan Ukuran Perusahaan sebagai Variabel Moderasi

H7: Pergantian Manajemen Berpengaruh Terhadap Voluntary Auditor Switching dengan Ukuran Perusahaan sebagai Variabel Moderasi

H8: Ukuran KAP Berpengaruh Terhadap Voluntary Auditor Switching dengan Ukuran Perusahaan sebagai Variabel Moderasi

H9: Opini Audit Berpengaruh Terhadap Voluntary Auditor Switching dengan Ukuran Perusahaan sebagai Variabel Moderasi

\section{METODE PENELITIAN}

Penelitian ini menggunakan data sekunder kuantitatif dengan metode analisis regresi logistik. Populasi yang digunakan menjadi obyek dalam penelitian ini adalah Perusahaan manufaktur yang menerbitkan laporan keuangan tahunan audited dan terdaftar pada Bursa Efek Indonesia (BEI) periode 2014 sampai 2018. Teknik sampling dalam penelitian ini menggunakan metode purposive sampling dengan kriteria tertentu. Kriteria pengambilan sampel dalam penelitian ini tersaji pada tabel 1 . Sampel penelitian: 
Tabel 1. Sampel penelitian

\begin{tabular}{clc}
\hline No & \multicolumn{1}{c}{ Keterangan } & Jumlah \\
\hline 1 & Jumlah Perusahaan manufaktur Tahun 2014 sampai dengan 2018 & 235 \\
2 & $\begin{array}{l}\text { Perusahaan manufaktur yang tidak terdaftar berturut-turut di BEI selama } \\
\text { periode 2014 sampai dengan 2018 }\end{array}$ & -37 \\
3 & $\begin{array}{l}\text { Perusahaan yang tidak mempublikasikan laporan auditan periode 2014 sampai } \\
\text { dengan 2018 }\end{array}$ & -11 \\
4 & Perusahaan manufaktur yang memiliki data tidak lengkap & -27 \\
5 & Perusahaan yang tidak melakukan penggantian KAP secara voluntary & -65 \\
Perusahaan sampel & 95 \\
Jumlah Tahun Pengamatan & 5 \\
Jumlah Sampel selama Periode Penelitian & 475 \\
\hline
\end{tabular}

Sumber: Data diolah 2019

\section{Operasional Variabel}

Variabel dependen $(Y)$ dalam penelitian ini adalah pergantian Kantor Akuntan Publik oleh perusahaan (Klien) (auditor switching). Kriteria

Variabel dependen dalam penelitian ini tersaji pada tabel 2. Variabel dependen:

Tabel 2. Variabel Dependen

\begin{tabular}{|c|c|c|c|}
\hline Variabel & Indikator & Skala & Sumber \\
\hline Voluntary Auditor & Jika perusahaan melakukan pergantian & \multirow[t]{11}{*}{ Nominal } & Pawitri, N. M. P., \& \\
\hline \multirow[t]{10}{*}{ Swiching $(\mathrm{Y})$} & kantor akuntan publik maka diberikan & & Yadnyana, K. (2015). \\
\hline & nilai 1 , dan jika tidak diberikan nilai 0 & & Pengaruh Audit Delay, \\
\hline & & & Opini Audit, Reputasi \\
\hline & & & Auditor dan Pergantian \\
\hline & & & Manajemen Pada \\
\hline & & & Voluntary Auditor \\
\hline & & & Switching Indonesia (BEI) \\
\hline & & & periode 2009-2013). E-jurnal \\
\hline & & & Akuntansi Universitas \\
\hline & & & Udayana. \\
\hline
\end{tabular}

Variabel independen $(X)$ mempengaruhi dalam penelitian ini tersaji pada tabel 3 . auditor switching. Kriteria Variabel dependen Variabel independen:

Tabel 3. Variabel independen

\begin{tabular}{|c|c|c|c|}
\hline Variabel & Indikator & Skala & Sumber \\
\hline $\begin{array}{l}\text { Financial Destress } \\
(\mathrm{X} 1)\end{array}$ & $\begin{array}{l}\text { a. Jika nilai } Z<1,23 \text { maka termasuk } \\
\text { perusahaan yang bangkrut } \\
\text { b. Jika nilai } 1,23<Z<2,9 \text { maka } \\
\text { termasuk grey area } \\
\text { c. Jika nilai } Z>2,9 \text { maka termasuk } \\
\text { perusahaan yang tidak bangkrut }\end{array}$ & Nominal & $\begin{array}{l}\text { Lesmana, K., \& Kurnia, R. } \\
\text { (2016). Analisis Pengaruh } \\
\text { Pergantina Manajemen, Opini } \\
\text { Audit Tahun Sebelumnya, } \\
\text { Financial Distress, Ukuran KAP, } \\
\text { dan Ukuran Perusahaan Klien } \\
\text { Terhadap Voluntary Auditor } \\
\text { Switching (Studi Pada } \\
\text { Perusahaan Manufaktur di BEI } \\
\text { Periode 2012-2014). Jakarta: } \\
\text { Ultima Accounting Vol } 8 . \\
\text { No.1. }\end{array}$ \\
\hline
\end{tabular}




$\begin{array}{ll}\text { Pergantian } & \text { Jika perusahaan melakukan } \\ \text { Manajeman (X2) } & \begin{array}{l}\text { pergantian Manajeman maka } \\ \text { diberikan nilai 1, dan jika tidak } \\ \text { diberikan nilai 0 }\end{array}\end{array}$

Ukuran KAP

(X3)

Opini Audit (X4)
Jika sebuah perusahaan diaudit oleh KAP big 4 maka diberi nilai 1 sedangkan jika diaudit oleh KAP non big 4 maka diberikan nilai 0

Jika sebuah perusahaan mendatkan opini tidak modifikasian maka diberi nilai 1 sedangkan jika modifikasian maka diberikan nilai 0

$\begin{array}{ll}\text { Nominal } & \text { Ella Soraya, Soraya, E., \& } \\ & \text { Haridhi, M. (2017). Faktor- } \\ & \text { Faktor Yang Mempengaruhi } \\ & \text { Voluntary Auditor Switching } \\ & \text { (Studi Empiris pada } \\ & \text { Perusahaan Non Financing } \\ & \text { yang Terdaftar di Bursa Efek } \\ & \text { Indonesia tahun 2011-2015). } \\ & \text { Jurnal Ilmiah Mahasiswa } \\ & \text { Ekonomi Akuntansi (JIMEKA) } \\ & \text { Vol. 2, No. 1, (2017) Halaman } \\ & \text { 48-62. } \\ & \text { Pawitri, N. M. P., \& Yadnyana, } \\ & \text { K. (2015). Pengaruh Audit } \\ & \text { Delay, Opini Audit, Reputasi } \\ \text { Auditor dan Pergantian } \\ \text { Manajemen Pada Voluntary } \\ \text { Auditor Switching Indonesia } \\ \text { (BEI) periode 2009-2013). E- } \\ \text { jurnal Akuntansi Universitas } \\ \text { Udayana. } \\ \text { Pawitri, N. M. P., \& Yadnyana, } \\ \text { K. (2015). Pengaruh Audit } \\ \text { Delay, Opini Audit, Reputasi } \\ \text { Auditor dan Pergantian } \\ \text { Manajemen Pada Voluntary } \\ \text { Auditor Switching Indonesia } \\ \text { (BEI) periode 2009-2013). E- } \\ \text { jurnal Akuntansi Universitas } \\ \text { Udayana. } \\ \end{array}$

Variabel Moderasi (M) merupakan variabel control dalam penelitian ini menggunakan ukuran perusahaan. Menurut Prasetia, at al. (2014) cerminan dari ukuran perusahaan dapat dilihat dari total aset yang dimiliki oleh perusahaan dan dapat dirumuskan sebagai berikut:

Size $=$ Ln of total asset

\section{HASIL DAN PEMBAHASAN}

Penelitian ini menguji dan menginvestigasi tentang pengaruh Financial Distress, Pergantian Manajemen, Ukuran KAP, dan Opini Audit terhadap Voluntary Auditor Swicthing dengan ukuran perusahaan sebagai variable pemoderasi. Objek penelitian adalah perusahaan yang termasuk pada sektor manufaktur di Bursa Efek Indonesia periode 2014-2108. Jumlah sampel sebanyak 95 perusahaan selama periode 20142018 sehingga diperoleh 475 data.

Hasil statistik deskriptif masing-masing variabel dari 475 sampel penelitian terdiri dari voluntary auditor switching, financial distress, pergantian manajemen, ukuran KAP, opini audit dan ukuran perusahaan terlihat pada table 4 statistik deskriptif: 
Tabel 4. Statistik Deskriptif

\begin{tabular}{lrrrrrrr}
\hline & N & \multicolumn{1}{c}{ Min } & Max & Mean & Std. Deivation & Skew. & E.Kurtoris \\
\hline Y & 475 & 0.000 & 1.000 & 0.453 & 0.498 & 0.190 & -1.964 \\
X1 & 475 & -3.556 & 32.491 & 2.398 & 3.754 & 3.594 & 19.823 \\
X2 & 475 & 0.000 & 1.000 & 0.141 & 0.348 & 2.062 & 2.254 \\
X3 & 475 & 0.000 & 1.000 & 0.596 & 0.491 & -0.390 & -1.848 \\
X4 & 475 & 0.000 & 1.000 & 0.989 & 0.102 & -9.592 & 90.011 \\
$\mathbf{M}$ & 475 & 25.216 & 38.475 & 28.508 & 1.746 & 0.832 & 1.667 \\
\hline
\end{tabular}

Sumber: Data diolah 2019

Variabel Auditor switching dengan nilai minimum 0.000 , nilai maksimum 1.000 , nilai mean 0.453 dan nilai standar deviasi 0.498, artinya sebesar $45 \%$ perusahaan manufaktur yang terdaftar di Bursa Efek Indonesia periode 2014-2018 melakukan auditor switching voluntary, sisanya 55\% tidak melakukan auditor switching voluntary.

Financial distress merupakan suatu kondisi dimana suatu perusahaan sedang dalam keadaan kesulitan keuangan. Financial distress memiliki variabel dengan nilai minimum -3.556, nilai maksimum 32.491, nilai mean 2.398 dan nilai standar deviasi 3.754. Nilai tersebut mengartikan bahwa 23\% perusahaan manufaktur terdaftar di Bursa Efek Indonesia yang mengalami financial distress, sehingga dapat disimpulkan bahwa sebagian besar perusahaan manufaktur tidak mengalami financial distress.

Pergantian manajemen merupakan pergantian direktur utama atau CEO (Chief Executive Oviccer) yang dilakukan oleh perusahaan. Variabel pergantian manajemen dengan nilai minimum 0.000 , nilai maksimum 1.000, nilai mean 0.141 dan nilai standar deviasi 0.348. Berdasarkan data, sebesar 14\% perusahaan manufaktur yang terdaftar di Bursa Efek Indonesia periode 2014-2018 melakukan pergantian manajemen, sehingga dapat disimpulkan sebagian besar perusahaan manufaktur di Bursa Efek Indonesia tidak melakukan pergantian manajemen.

Ukuran KAP dapat diartikan sebagai besar atau kecilnya KAP itu sendiri dimana KAP yang dikatakan besar adalah KAP yang memiliki reputasi. Ukuran KAP memiliki variabel dengan nilai minimum 0.000, nilai maksimum 1.000, nilai mean 0.596 dan nilai standar deviasi 0.491 mengartikan bahwa 59\% perusahaan manufaktur yang terdaftar di Bursa Efek Indonesia periode 2014-2018 telah diaudit oleh KAP yang bereputasi, yaitu KAP yang berafiliasi dengan KAP Big-four.

Opini audit adalah hasil atau pendapat yang diberikan oleh seorang auditor atas laporan keuangan yang telah diaudit. Variabel opini audit dengan nilai minimum 0.000 , nilai maksimum 1.000, nilai mean 0.989 dan nilai standar deviasi 0.102 mengartikan bahwa 98\% perusahaan manufaktur yang terdaftar di Bursa Efek Indonesia periode 2014-2018 memiliki opini wajar tanpa modifikasi untuk laporan tahunannya.

Ukuran perusahaan (Size) adalah untuk mengukur seberapa besar perusahaan yang digunakan sebagai sampel penelitian yang diproksikan dengan Ln total asset. Semakin tinggi Ln total asset maka semakin besar perusahaan. Variabel SIZE dengan nilai minimum 25.216, nilai maksimum 38.475 , nilai mean 28.508 dan nilai standar deviasi 1.746. Kekayaan rata-rata dari keseluruhan perusahaan sampel selama periode penelitian 28.508 atau senilai $\mathrm{Rp}$ 596,926,505,125.761yang artinya merupakan perusahaan yang masuk kategori perusahaan besar.

\section{Uji Determinasi Dan Uji Kelayakan Model}

Hasil uji evaluasi model pengukuran (outer model evaluation) dilihat dari nilai R-Square dan Average blok VIF (AVIF). Tabel 5. Hasil Uji RSquare Dan Goodnes of Fit menampilkan masing-masing nilai R-Square dan Average blok VIF (AVIF) yang telah diolah menggunakan SmartPLS 5.0. 
Tabel 5. Hasil Uji R-Square Dan Goodnes of Fit

\section{Komponen}

Average path coefficient

Average adjusted R-squared

Average blolk VIF (AVIF)

Sumber: Data diolah 2019

Berdasarkan hasil tabel 4.5 terlihat nilai RSquare sebesar 0.136, (Ghazali, 2011) besaran nilai R-Square dapat dikelompokan menjadi 3 bagian yaitu: (1) kategori kuat dengan nilai RSquare $>=0.67$; (2) kategori moderate dengan nilai $0.33<=$ R-Square <0.67; (3) kategori lemah dengan nilai $0.19<=\quad$ R-Square $>0.33$. Hal ini dapat diartikan bahwa variabilitas voluntary auditor switching yang dapat dijelaskan oleh financial distress, pergantian manajemen, ukuran KAP, dan opini audit dimoderasi ukuran perusahaan sebesar $15 \%$, sedangkan sisanya $85 \%$ dijelaskan oleh variabel lain yang tidak diteliti dalam model.

Nilai APC memiliki indeks sebesar 0.076 dengan nilai $\mathrm{p}$-value 0.024. Sedangkan ARS memiliki indeks sebesar 0.136 dengan p-value $<0.001$. Nilai P-value dari kedua indeks menunjukkan hasil dibawah 0.05 (pada alpha $5 \%$ ) yang berarti memenuhi kriteria APC dan ARS. Nilai AVIF yang dihasilkan juga menunjukan indeks dibawah 5 yaitu sebesar 1.162. Sehingga dapat ditarik kesimpulan bahwa model mampu memprediksi nilai observasinya atau dapat dikatakan model dapat diterima karena cocok dengan data observasinya (Ghozali, 2011).

\section{Hasil Uji Full Model}

Model struktural yang sudah memiliki goodness of fit model dan uji predictive relevance dapat dilakukan uji full model. Nilai uji full model ialah nilai yang menunjukkan tingkat signifikansi pada pengujian hipotesis. Uji signifikansi koefisien jalur dengan menggunakan metode bootstrapping. Setelah mengetahui validitas dan reliabilitas item masing-masing variabel melalui analisis menggunakan SmartPLS dan hasil uji koefisiensi parameter jalur. Peneliti melakukan uji hipotesis, pengujian hipotesis ini didasarkan pada tingkat signifikansi $10 \%$ (P-values < 0.1 ). Hasil uji full model tersebut akan dijelaskan pada gambar di bawah ini:

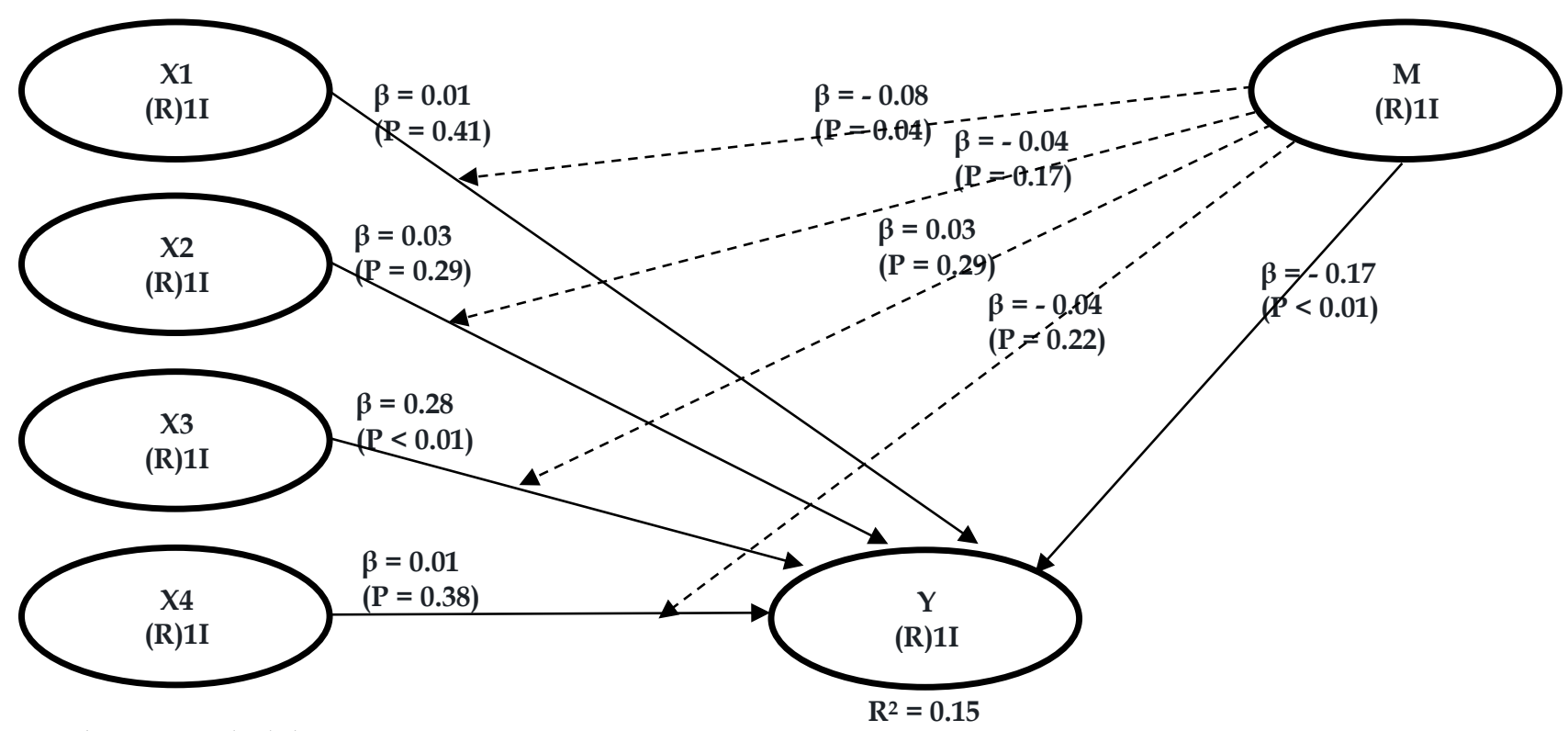

sumber: Data diolah 2019 
Keterangan:

Y : Voluntary Auditor Switching

$\mathrm{X} 1$ : Financial Distress

X2: Pergantian Manajemen

X3: Ukuran KAP

X4 : Opini Audit

M: Ukuran Perusahaan
Berdasarkan gambar tersebut terlihat hasil uji full model terhadap 5 variabel independen, 1 variabel moderasi terhadap variabel dependen. Demi memudahkan dalam pengambilan kesimpulan, maka pengujian full model ini akan dirangkum dalam satu tabel dibawah ini guna memudahkan dalam menganalisis pada uji hipotesis selanjutnya. Hasil Pengujian full model disajikan pada tabel 6 berikut ini:

Tabel 6. Rangkuman Hasil Uji Hipotesis

\begin{tabular}{lllrrlll}
\hline Hipotesis & Path & Effect & Coefficient & P-value & $\begin{array}{c}\text { Signifikan } \\
\text { /Tidak }\end{array}$ & $\begin{array}{l}\text { Diterima } \\
\text { /Ditolak }\end{array}$ & Keterangan \\
\hline $\mathrm{H} 1$ & $\mathrm{X} 1 \rightarrow \mathrm{Y}$ & Direct & 0.011 & 0.408 & Tidak & Ditolak & - \\
$\mathrm{H} 2$ & $\mathrm{X} 2 \rightarrow \mathrm{Y}$ & Direct & 0.025 & 0.292 & Tidak & Ditolak & - \\
$\mathrm{H} 3$ & $\mathrm{X} 3 \rightarrow \mathrm{Y}$ & Direct & -0.278 & $<0.001$ & Signifikan & Diterima & - \\
$\mathrm{H} 4$ & $\mathrm{X} 4 \rightarrow \mathrm{Y}$ & Direct & -0.013 & 0.384 & Tidak & Ditolak & - \\
$\mathrm{H} 5$ & $\mathrm{X} 5 \rightarrow \mathrm{Y}$ & Direct & -0.174 & $<0.001$ & Signifikan & Diterima & - \\
$\mathrm{H} 6$ & $\mathrm{X} 1^{*} \mathrm{M} \rightarrow \mathrm{Y}$ & Direct & -0.080 & 0.039 & Signifikan & Diterima & Pure Moderator \\
$\mathrm{H} 7$ & $\mathrm{X} 2^{*} \mathrm{M} \rightarrow \mathrm{Y}$ & Direct & -0.043 & 0.171 & Tidak & Ditolak & Homologiser Moderator \\
$\mathrm{H} 8$ & $\mathrm{X} 3^{*} \mathrm{M} \rightarrow \mathrm{Y}$ & Direct & 0.025 & 0.291 & Tidak & Ditolak & Prediktor Moderasi \\
$\mathrm{H} 9$ & $\mathrm{X} 4^{*} \mathrm{M} \rightarrow \mathrm{Y}$ & Direct & -0.036 & 0.218 & Tidak & Ditolak & Homologiser Moderator \\
\hline
\end{tabular}

sumber: Data diolah 2019

Berdasarkan hasil uji hipotesis pada tabel 4 diatas, dapat disimpulkan bahwa dari ke 9 (sembilan) hipotesis yang diajukan, terdapat 6 hipotesis yang ditolak atau tidak dapat dibuktikan pengaruhnya dikarenakan memiliki nilai P-Value $>0.1$ yaitu pada variable financial distress, variable pergantian manajemen, variable opini audit, variable pergantian manajemen yang di moderasi oleh ukuran perusahaan, variable ukuran KAP yang dimoderasi oleh ukuran perusahaan, dan variable opini audit yang dimoderasi oleh ukuran perusahan. Sedangkan 3 hipotesis diterima atau terbukti memiliki pengaruh dikarenakan memiliki nilai P-Value $<0.1$ yaitu pada variabel ukuran KAP, variable ukuran perusahan, dan variable financial distress yang dimoderasi oleh ukuran perusahaan.

\section{Pengaruh Financial Distress terhadap Voluntary Auditor Switching}

Financial distress dapat didefinisikan sebagai tahap penurunan kondisi keuangan yang terjadi sebelum terjadinya kebangkrutan ataupun likuidasi. Menurut Plat (2002), kesulitan keuangan adalah masalah likuiditas yang sangat parah yang tidak bisa dipecahkan tanpa perubahan ukuran dari operasi atau struktur perusahaan

Pada penelitian Agiastuti dan Saputra (2012) menemukan bahwa semakin besar financial distress perusahaan semakin besar voluntary auditor switching dan sebaliknya semakin kecil financial distress semakin kecil pula voluntary auditor switching yang dilakukan oleh perusahaan.

Berdasarkan hasil uji hipotesis pertama (H1) pada tabel 4.5 didapatkan bahwa nilai koefisien sebesar 0.011 dengan tingkat signifikansi (P-value) sebesar 0.408. Dapat disimpulkan bahwa financial distress berpengaruh positif terhadap voluntary auditor switching, namun tidak berpengaruh signifikan dikarenakan nilai P-value $>10 \%$ yang menunjukkan bahwa hipotesis pertama (H1) ditolak.

Hasil penelitian oleh Hidayati dan Sari, dkk (2018) yang membuktikan bahwa kesulitan 
keuangan tidak menjadi faktor yang mendorong suatu perusahaan untuk berganti KAP.yang membuktikan bahwa kesulitan keuangan tidak menjadi faktor yang mendorong suatu perusahaan untuk berganti KAP. Perusahaan dalam kondisi financial distress cenderung tidak melakukan pergantian KAP karena bila pergantian auditor terlalu sering dilakukan, maka biaya audit yang dikeluarkan oleh perusahaan juga akan bertambah. Hal ini disebabkan saat auditor pertama kali mengaudit suatu klien, hal pertama yang dilakukan adalah memahami lingkungan bisnis klien dan risiko audit klien. Sehingga berakibat pada tingginya biaya star up dan menaikkan fee audit.

\section{Pengaruh Pergantian Manajemen terhadap Voluntary Auditor Switching}

Pergantian manajemen merupakan pergantian direksi perusahaan yang dapat disebabkan karena keputusan Rapat Umum Pemegang Saham (RUPS) atau kemauan sendiri dari direksi untuk berhenti. Menurut Wea dan Murdiawati (2015) adanya manajemen yang baru mungkin juga diikuti oleh perubahan kebijakan di bidang akuntansi, keuangan dan pemilihan KAP.

Berdasarkan hasil uji hipotesis kedua (H2) pada tabel 4.5 diperoleh nilai koefisien sebesar 0.025 dengan tingkat signifikansi (P-value) sebesar 0.292. Hal ini berarti pergantian manajemen tidak berpengaruh signifikan terhadap voluntary auditor switching dikarenakan nilai P-value $>10 \%$. Dengan ini dapat disimpulkan bahwa hipotesis kedua (H2) ditolak.

Hasil penelitian ini tidak mendukung penelitian sebelumnya yang dilakukan oleh Pawitri dan Yadnyana (2015) yang membuktikan bahwa pergantian manajemen berpengaruh positif signifikan terhadap voluntary auditor switching. Pergantian manajemen biasanya menyebabkan perubahan kebijakankebijakan, salah satunya seperti penunjukkan KAP maupun seorang akuntan publik.

Hasil penelitian ini sejalan dengan Kurniaty (2015) yang menunjukkan pergantian manajemen bukan faktor yang menyebabkan perusahaan melakukan auditor switching. Hal ini menunjukkan bahwa negosiasi ulang dapat dilakukan agar kebijakan dan laporan auditor independen KAP sebelumnya tetap dapat diselaraskan dengan kebijakan manajemen yang baru.

\section{Pengaruh Ukuran KAP terhadap Voluntary Auditor Switching}

DeFond (1992) menyatakan bahwa kualitas audit dapat juga ditentukan oleh ukuran dari Kantor Akuntan Publik itu sendiri. KAP yang berukuran kecil memiliki sumber daya yang lebih terbatas, yang kemudian dipersepsikan kualitasnya lebih rendah. KAP besar memiliki reputasi yang lebih baik dalam mempertahankan tingkat independensinya dibandingkan dengan KAP kecil karena KAP besar ini melayani banyak klien dan ini mengurangi ketergantungan KAP besar pada klien tertentu sesuai pendapat Wilson dan Grimlund dalam Wijaya (2013).

Berdasarkan hasil uji hipotesis ketiga $(\mathrm{H} 3)$ pada tabel 4.5 diperoleh bahwa nilai koefisien sebesar -0.278 dengan tingkat signifikansi ( $\mathrm{P}$ value) sebesar <0.001. Dapat disimpulkan ukuran KAP berpengaruh negatif signifikan terhadap voluntary auditor switching dikarenakan nilai P-value $>10 \%$, hal ini menunjukkan bahwa hipotesis ketiga (H3) diterima.

Hasil penelitian ini mendukung Pawitri dan Yadnyana (2015) yang membuktikan bahwa ukuran KAP berpengaruh signifikan terhadap voluntary auditor switching. KAP yang lebih besar (Big-four) dianggap lebih mampu untuk mempertahankan independensi yang memadai daripada rekan-rekan mereka yang lebih kecil karena dapat menyediakan berbagai layanan untuk klien dalam jumlah yang lebih besar, sehingga mengurangi ketergantungan mereka pada klien tertentu.

Hasil penelitian tidak sependapat dengan Manta dan Manda (2014) yang menyatakan bahwa variabel ukuran KAP tidak berpengaruh terhadap auditor switching. Perubahan kelas KAP dari Big four dikhawatirkan dapat menimbulkan sentimen negatif di kalangan pelaku pasar terhadap kualitas pelaporan keuangan dari perusahaan. Di sisi lain, dikhawatirkan 
perubahan dari kelas KAP ke Big four, dengan mempertimbangkan kualitas ujian yang lebih baik, tidak membuka peluang untuk memperoleh opini unqualified karena pertimbangan kualitas audit yang lebih baik.

\section{Pengaruh Opini Audit Terhadap} Voluntary Auditor Switching

Menurut Wea dan Murdiawati (2015) Opini audit merupakan hasil atau pendapat yang diberikan oleh seorang auditor atau Kantor Akuntan Publik terhadap laporan keuangan perusahaan klien yang sudah diaudit. Manajemen perusahaan selalu menginginkan opini yang baik agar bisa menarik perhatian para investor untuk berinvestasi pada perusahaan setelah melihat laporan keuangan yang mempunyai kualitas bagus.

Penelitian yang dilakukan Kristiawan (2017) menunjukkan bahwa kualitas opini yang dikeluarkan oleh auditor dapat menentukan perusahaan untuk melakukan auditor switching. Jika auditor tidak dapat memberikan opini wajar tanpa pengecualian (unqualified opinion), maka perusahaan cenderung akan melakukan mengganti dengan KAP yang memungkinkan untuk dapat memberikan opini yang sesuai dengan yang diharapkan perusahaan. Pihak manajemen akan memberhentikan auditornya atas opini yang tidak diharapkan oleh perusahaan dan perusahaan akan terus mencari auditor yang akan memberikan opini yang sesuai dengan harapannya.

Berdasarkan hasil uji hipotesis keempat (H4) pada tabel 4.5 diperoleh nilai koefisien sebesar -0.013 dengan tingkat signifikansi ( $\mathrm{P}$ value) sebesar 0.384, dapat disimpulkan bahwa opini audit tidak berpengaruh terhadap voluntary auditor switching dikarenakan nilai Pvalue $>10 \%$. Hal ini menunjukkan bahwa hipotesis keempat (H4) ditolak.

Penelitian ini selaras dengan Nasir (2018), Widnyani dan Muliaartha (2018) dan Juliantari dan Rasmini (2013) yang menyatakan perusahaan yang menggunakan auditor baru akan menerima opini yang sama, atau opini yang tidak jauh berbeda dari opini yang diberikan auditor sebelumnya, karena auditor baru akan tetap melihat laporan auditor independen KAP sebelumnya.

\section{Pengaruh Ukuran Perusahaan terhadap Voluntary Auditor Switching}

Menurut Wea dan Murdiawati (2015) ukuran perusahaan merupakan skala yang dapat diukur dari segi keuangan dengan melihat total asset. Semakin besar total asset yang dimiliki oleh perusahaan menunjukan bahwa perusahaan tersebut semakin besar, dan sebaliknya.

Berdasarkan hasil uji hipotesis kelima (H5) pada tabel 4.5 didapatkan bahwa nilai koefisien sebesar -0.174 dengan tingkat signifikansi ( $\mathrm{P}$ value) sebesar $<0.001$, dapat disimpulkan bahwa opini audit tidak berpengaruh terhadap voluntary auditor switching dikarenakan nilai Pvalue $>10 \%$, hal ini menunjukkan bahwa hipotesis kelima (H5) diterima.

Temuan penelitian ini tidak mendukung penelitian Kurniawan (2017) yang menunjukkan temuan bahwa ukuran perusahaan tidak dapat mempengaruhi perusahaan ketika mengganti auditor. Pelaksanaan pergantian auditor di Indonesiaumumnya memiliki hubungan yang sejalan antara KAP dengan perushaannya. Ukuran perusahaan yang kecil atau perusahaan dengan total aset rendah cenderung menggunakan KAP kecil, sedangkan perusahaan besar atau perusahaan dengan total aset tinggi akan menggunakan KAP besar atau Big-Four. Oleh karena itu, perusahaan besar cenderung tidak mengganti auditor untuk menghindari biaya keagenan dan menjaga kualitas audit.

Hasil penelitian menunjukan arah negatif pada hubungan voluntary auditor switching dan perusahaan besar. Perusahaan skala besar tentunya memiliki kompleksititas tinggi karena nilai total aset yang dimiliki dan intensitas operasional yang cukup besar pula. Keadaan ini, membuat ketidakcenderungan pengambilan keputusan voluntary auditor switching pada perushaan besar dan lebih memilki preferensi untuk diaudit oleh KAP yang memiliki reputasi atau yang berafiliasi dengan the big four. Hal ini sejalan dengan hasil penelitian Kurniaty (2014) serta Wea dan Murdiawati (2014) menunjukan bahwa auditor switching dipengaruhi oleh 
ukuran perusahaan.

\section{Pengaruh Financial Distress terhadap Voluntary Auditor Switching dengan Ukuran Perusahaan sebagai Moderasi}

Pada hipotesis pertama telah dibuktikan bahwa tidak terdapat pengaruh antara financial distress terhadap voluntary auditor switching dan pada hipotesis kelima terdapat pengaruh ukuran perusahaan terhadap voluntary auditor switching, untuk menciptakan pembaharuan penelitian, penulis mencoba menghubungkan jika ukuran perusahaan dapat memperkuat pengaruh financial distress terhadap voluntary auditor switching, yang mana ukuran perusahaan yang memiliki total asset yang besar lebih memilih diaudit oleh KAP yang bereputasi.

Berdasarkan hasil uji hipotesis keenam (H6) pada tabel 4.5 didapatkan bahwa nilai koefisien sebesar -0.080 dengan tingkat signifikansi ( $\mathrm{P}$ value) 0.039 , dikarenakan nilai $\mathrm{P}$-value $<10 \%$, hal ini menunjukkan bahwa hipotesis keenam (H6) diterima.

Nilai koefisien negatif mengindikasikan bahwa ukuran perusahaan memiliki pengaruh negatif terhadap pengaruh financial distress terhadap voluntary auditor switching. Peningkatan financial distress diiringi penurunan ukuran perusahaan menyebabkan kenaikan terhadap voluntary auditor switching. Tipe moderasi yang terjadi merupakan tipe pure moderation (moderasi murni) yang artinya bahwa ukuran perusahaan terbukti mampu menjadi variable pemoderasi untuk pengaruh financial distress terhadap voluntary auditor switching.

\section{Pengaruh Pergantian Manajemen terhadap voluntary auditor switching dengan Ukuran Perusahaan sebagai Moderasi}

Pada hipotesis kedua telah dibuktikan bahwa tidak terdapat pengaruh antara pergantian manajemen terhadap voluntary auditor switching dan pada hipotesis kelima terdapat pengaruh ukuran perusahaan terhadap voluntary auditor switching, namun sebagai keterbaharuan penelitian maka penulis mencoba menghubungkan apakah ukuran perusahaan dapat memperkuat pengaruh pergantian manajemen terhadap voluntary auditor switching, yang mana ukuran perusahaan yang memiliki total asset yang besar lebih memilih diaudit oleh KAP yang bereputasi.

Berdasarkan hasil uji hipotesis ketujuh (H7) pada tabel 4.5 didapatkan bahwa nilai koefisien sebesar 0.043 dengan tingkat signifikansi ( $\mathrm{P}$ value) 0.171 , dikarenakan nilai $\mathrm{P}$-value $>10 \%$, hal ini menunjukkan bahwa hipotesis ketujuh (H7) ditolak.

Hal tersebut mengindikasikan bahwa ukuran perusahaan memperlemah pengaruh pergantian manajemen terhadap voluntary auditor switching, namun pengaruhnya tidak signifikan. Tipe moderasi yang terjadi merupakan homologiser moderation, yang artinya bahwa ukuran perusahaan sebenarnya memiliki potensi untuk menjadi variable moderasi. Variabel ukuran perusahaan tidak berinteraksi dengan pergantian manajemen.

\section{Pengaruh Ukuran KAP terhadap Voluntary Auditor Switching dengan Ukuran Perusahaan sebagai Moderasi \\ Pada hipotesis ketiga telah dibuktikan} bahwa terdapat pengaruh antara ukuran KAP terhadap voluntary auditor switching dan pada hipotesis kelima terdapat pengaruh ukuran perusahaan terhadap voluntary auditor switching, namun sebagai pembaruan penelitian, penulis mencoba menghubungkan apakah ukuran perusahaan dapat digunakan memperkuat pengaruh ukuran KAP terhadap voluntary auditor switching, yang mana ukuran perusahaan yang memiliki total asset yang besar lebih memilih diaudit oleh KAP yang bereputasi.

Berdasarkan hasil uji hipotesis ketujuh (H7) pada tabel 4.5 didapatkan bahwa nilai koefisien sebesar 0.025 dengan tingkat signifikansi (Pvalue) 0.291 , dikarenakan nilai $\mathrm{P}$-value $>10 \%$, hal ini menunjukkan bahwa hipotesis kedelapan (H8) ditolak.

Hasil tersebut mengindikasikan bahwa adanya ukuran perusahaan justru melemahkan pengaruh ukuran KAP terhadap voluntary auditor switching. Peningkatan financial distress diiringi peningkatan ukuran perusahaan belum mampu menurunkan voluntary auditor 
switching. Tipe moderasi ini adalah tipe predictor moderation yang artinya bahwa ukuran perusahaan terbukti tidak dapat menjadi variabel pemoderasi untuk pengaruh ukuran KAP terhadap voluntary auditor switching, hanya dapat menjadi variabel eksogen.

\section{Pengaruh Opini Audit terhadap Voluntary Auditor Switching dengan Ukuran Perusahaan sebagai Moderasi}

Pada hipotesis keempat telah dibuktikan bahwa tidak terdapat pengaruh antara opini audit terhadap voluntary auditor switching dan pada hipotesis kelima terdapat pengaruh ukuran perusahaan terhadap voluntary auditor switching, namun sebagai keterbaharuan penelitian, penulis mencoba mengaitkan jika ukuran perusahaan dapat memperkuat pengaruh opini audit terhadap voluntary auditor switching, yang mana ukuran perusahaan yang memiliki total asset yang besar lebih memilih diaudit oleh KAP yang bereputasi.

Berdasarkan hasil uji hipotesis kesembilan (H9) pada tabel 4.5 didapatkan bahwa nilai koefisien sebesar -0.036 dengan tingkat signifikansi (P-value) 0.213, dikarenakan nilai Pvalue $>10 \%$, hal ini menunjukkan bahwa hipotesis kesembilan (H9) ditolak.

Hasil tersebut mengindikasikan bahwa ukuran perusahaan memperlemah pengaruh opini audit terhadap voluntary auditor switching, namun pengaruhnya tidak signifikan. Tipe moderasi yang terjadi merupakan homologiser moderation, yang artinya bahwa ukuran perusahaan sebenarnya memiliki potensi untuk menjadi variable moderasi.

\section{SIMPULAN}

Berdasarkan data penelitian dan hasil uji yang dilakukan, dapat ditarik kesimpulan. Financial Distress tidak berpengaruh terhadap voluntary auditor switching. Hasil penelitian ini memberikan bukti bahwa Kesulitan ekonomi bukanlah faktor yang mendorong perusahaan untuk mengubah CAP. Perusahaan dalam kesulitan keuangan cenderung tidak mengubah CAP karena seringnya pergantian auditor di perusahaan yang meningkatkan biaya audit. Audit tahun pertama, hal pertama yang dilakukan auditor adalah memahami lingkungan bisnis dan risiko audit. Sehingga berakibat pada tingginya biaya star up dan menaikkan fee audit.

Pergantian manajemen tidak berpengaruh pada perubahan sukarela auditor. Hasil penelitian ini memberikan bukti bahwa pergantian manajemen bukanlah faktor yang menyebabkan perusahaan mengganti auditor. Hal ini menunjukkan bahwa kebijakan akuntansi dan pelaporan KAP yang lama masih dapat diselaraskan dengan kebijakan manajemen yang baru melalui renegosiasi.

Ukuran KAP berpengaruh negative signifikan terhadap voluntary auditor switching. Hasil penelitian ini memberikan bukti bahwa KAP terbesar (big four) diyakini lebih mampu mempertahankan independensi yang wajar daripada rekan-rekan mereka yang lebih kecil karena mereka dapat menawarkan berbagai layanan kepada lebih banyak klien, sehingga mengurangi ketergantungan mereka pada klien tertentu.

Opini Audit tidak berpengaruh terhadap voluntary auditor switching. Hasil penelitian ini memberikan bukti bahwa perusahaan yang menggunakan auditor baru akan menerima opini yang sama, atau opini yang tidak jauh berbeda dari opini yang diberikan auditor sebelumnya, karena auditor baru akan mencari informasi atas opini yang akan diberikan melalui auditor lama.

Ukuran perusahaan berpengaruh negative signifikan terhadap voluntary auditor switching. Hasil penelitian ini memberikan bukti bahwa ukuran perusahaan mempengaruhi perubahan sukarela auditor. Arah negatif menunjukkan bahwa perusahaan besar cenderung tidak mengambil keputusan untuk mengganti auditor. Perusahaan besar memiliki tingkat kerumitan yang tinggi. Perusahaan yang memiliki total nilai aset yang besar lebih memilih untuk dikendalikan oleh KAP yang bereputasi baik atau KAP yang berafiliasi dengan Big Four.

Tipe moderasi ukuran perusahaan atas pengaruh financial distress terhadap voluntary auditor switching adalah tipe pure moderation (moderasi murni) yang artinya bahwa ukuran 
perusahaan terbukti mampu menjadi variable pemoderasi untuk pengaruh financial distress terhadap voluntary auditor switching.Tipe moderasi ukuran perusahaan atas pengaruh pergantian manajemen terhadap voluntary auditor switching adalah tipe homologiser moderation, yang artinya bahwa ukuran perusahaan sebenarnya memiliki potensi untuk menjadi variable moderasi. Variabel ukuran perusahaan tidak berinteraksi dengan pergantian manajemen. Tipe moderasi ukuran perusahaan atas pengaruh ukuran KAP terhadap voluntary auditor switching adalah tipe predictor moderation yang artinya bahwa ukuran perusahaan terbukti tidak dapat menjadi variabel pemoderasi untuk pengaruh ukuran KAP terhadap voluntary auditor switching, hanya dapat menjadi variabel eksogen.Tipe moderasi ukuran perusahaan atas pengaruh opini audit terhadap voluntary auditor switching adalah tipe homologiser moderation, yang artinya bahwa ukuran perusahaan sebenarnya memiliki potensi untuk menjadi variable moderasi. Variabel ukuran perusahaan tidak berinteraksi dengan opini audit.

\section{REFERENSI}

Agiastuti,I. A. P., \& Suputra, I. D. G. D. (2016). Faktor-Faktor Yang Mepengaruhi Pada Voluntary Auditor SwitchingEJurnal Akuntansi Universitas Udayana Vol.17.1. Oktober (2016): 56-83.

Agoes, Sukrisno. (2014). Auditing Petunjuk Praktis Pemeriksaan Akuntan oleh Akuntan Publik, Edisi Keempat. Jakarta: Salemba Empat.

Andreas, Enni Savitri. (2019). Behavior Auditor Switching Behavior In LQ45 Companies In Indonesia.

Bursa Efek Indonesia. Laporan Keuangan Tahunan. Diakses 11 Juni 2019.http://www.idx.co.id/id.id/bera nda/perusahaantercatat/laporan keuangandantahunan.aspx.

Dircktory 2015 sampai dengan 2019 Kantor Akuntan Publik dan Akuntan Publik, Institut Akuntan Publik Indonesia.
Elder, A. A. R. J. A., \& Beasley, M. S. (2014). Auditing and Assurance Services: An Integrated Approach. Amerika Serikat: Pearson.

Faradila, Y., Yahya, M. R. (2016). Pengaruh Opini Audit, Financial Distress, Dan Pertumbuhan Perusahaan Klien Terhadap Auditor Switching (Studi pada Perusahaan Manufaktur yang Terdaftar di Bursa Efek Indonesia Tahun 2010-2014).

Ghozali, I. (2007). Aplikasi Analisis Multivariatif dengan Program SPSS. Semarang: Universitas Diponegoro.

Hidayati, W. N. (2018). Pengaruh Audit Delay, Reputasi Auditor, Pergantian Manajemen, Financial Distress, Pertumbuhan Perusahaan dan Kepemilikan Publik Terhadap Auditor Swiching pada Perusahan Go Public yang terdaftar di Bursa Efek Indonesia (BEI) Periode 2010-2015 Scientific. Journal of Reflection: $p$-ISSN 2615-3009 Economic, Accounting, Management and Bussines e-ISSN 26213389 Vol. 1, No. 4, Oktober 2018.

Ismanto, J., \& Manda, D. L. (2018). Pengaruh Financial Distress, Pergantian

Manajemen dan Ukuran KAP Terhadap Auditor Switching.

Juliantari, N. W. A., \& Rasmini, N. K. (2013). Auditor dan Faktor-Faktor yang Mempengaruhinya ISSN: 2302-8556 E-Jurnal Akuntansi Universitas Udayana 3.3 (2013): 231-246.

Kasih, M., \& Puspitasari, E. (2017). Auditor Swiching's Factor: The Analisys on Audit Delay, Client Size, and Audit Committee Changes.

Keputusan Ketua Badan Pengawas Pasar Modal Kep-11/PM/1997 tentang pedoman mengenai bentuk dan isi pernyataan pendaftaran dalam rangka penawaran umum oleh perusahaan menengah atau kecil.

Keputusan Menteri Keuangan Republik Indonesia Nomor 359 Tahun 2003 tentang Perubahan atas Keputusan Menteri Keuangan Republik Nomor 
432 Tahun 2002 tentang Jasa Akuntan Publik.

Kristian, M. (2015). Pengaruh Kepemilikan Publik, Petumbuhan Perusahaan, dan Ukuran Kantor Akuntan Publik Terhadap Penggantian Auditor (Studi pada Perusahaan Indeks Kompas100 Periode 2011-2013).

Kristiawan, Agus. (2015). Analisa Pengaruh Ukuran KAP, Opini Audit, Ukuran Perusahaan, Dan Profitabilitas Perusahaan Terhadap Auditor Switching (Studi Empiris pada Perusahaan Manufaktur yang Terdaftar di Bursa Efek Indonesia Periode 2010-2015).

Kurniaty, V., Hasan, A., \& Anisma, Y. (2013). Pengaruh Pergantian Manajeman, Opini Audit, Financial Distress, Ukuran KAP, dan Ukuran Perusahaan Klien Terhadap Auditor Switching pada Perusahaan Real Estate dan Properti di Bursa Efek Indonesia. Journal of Faculty of economic Riau University, Pekanbaru, Indonesia.

Kusuma, H. (2019) \& Likelihood of Auditor Switching: Evidence for Indonesia.

Lesmana, K., \& Kurnia, R. (2016). Analisis Pengaruh Pergantina Manajemen, Opini Audit Tahun Sebelumnya, Financial Distress, Ukuran KAP, dan Ukuran Perusahaan Klien Terhadap Voluntary Auditor Switching (Studi Pada Perusahaan Manufaktur di BEI Periode 2012-2014). Jakarta: Ultima Accounting Vol 8. No.1.

Meidiyustiani, R. (2018). Implementation of Regression Logistics for Audit Switching. International Journal of Pure and Applied Mathematics.

Nasir, Anisa. (2018). Pengaruh Opini Audit, Pergantian Manajemen dan Fee Audit Terhadap Auditor Swiching dengan Financial Distress Sebagai Variabel Moderasi, (Studi Empiris Pada Perusahaan Real Estate \& Property Yang Terdaftar di Bursa Efek Indonesia (BEI) Tahun 2011-2016). JOM
FEB, Volume 1 Edisi 1 (Januari - Juni 2018).

Pawitri, N. M. P., \& Yadnyana, K. (2015). Pengaruh Audit Delay, Opini Audit, Reputasi Auditor dan Pergantian Manajemen Pada Voluntary Auditor Switching Indonesia (BEI) periode 2009-2013). E-jurnal Akuntansi Universitas Udayana.

Peraturan Menteri Keuangan Nomor 17 Tahun 2008 tentang Jasa Akuntan Publik.

Peraturan Pemerintah No. 20/2015 tentang Praktik Akuntan Publik. Dalam PP No. 20/2015 pasal 11 ayat (1) dijelaskan bahwa KAP tidak lagi dibatasi dalam melakukan audit atas suatu perusahaan.

Pemerintah Republik Indoensia Keputusan Menteri Keuangan Nomor 423/KMK.06/2002 yang diubah dengan Keputusan Menteri Keuangan (KMK) No.359/KMK.06/2003 dan disempurnakan dengan Peraturan Menteri Keuangan No.17/PMK.01/2008 tentang Jasa Akuntan Publik.

Putra, I. W. D. W., (2014). Pengaruh Financial Distress, Rentabilitas, Pertumbuhan Perusahaan dan Opini Audit Pada Pergantian Auditor ISSN: 2302-8556 E-Jurnal Akuntansi Universitas Udayana 8.2 (2014): 308-323.

Pradipta, S. A. P. (2015). Analisa Hubungan Auditor Klien Faktor-faktor yang Mempengaruhi Auditor Switching (Studi Empiris pada Perusahaan Manufaktur yang Terdaftar di Bursa Efek Indonesia).

Rahayu, M. E. S. (2015). Analisa Pengaruh Opini Audit, Ukuran Kantor Akuntan Publik (KAP), Ukuran Perusahaan Klien, dan Kepemimilikan Manajerial Terhadap Auditor Swictching (Studi Empiris Pada Perusahaan Manufaktur Subsektor Makanan dan Minuman, Farmasi, Rokok yang Terdaftar di Bursa Efek Indonesia (BEI) periode 2009-2013). 
Rahmawati, D., Isynuwardhana, D., \& Yudowati, S. P. (2017). Pengaruh Pergantian Manajemen, Opini Audit, Pertumbuhan Perusahaan, dan Financial Distress Terhadap Auditor Switching (Studi pada Perusahaan Manufaktur yang Terdaftar di Bursa Efek Indonesia tahun 2010-2015.

Rahmawati, T. B., \& Probohudono, B. A N. (2017). Determinants Of Downward Auditor Switching. Jurnal Universitas Atma Jaya Yogyakarta, Caturtunggal, Kec. Depok, Sleman 55281 1), Universitas Sebelas.

Robbitasari, A. P., \& Wiratmaja, I. D. N. (2013). Pengaruh Opini Audit Going Concern, Kepemilikan Institusional dan Audit Delay Pada Voluntary Auditor Switching, E- Jurnal Universitas Udayana 5.3 (2013) : 652-665.

Saidin, R.A., \& Andini, R. (2016). Analysis Of Effect of Audit Opinion, KAP Size, Financial Trouble, Turn Managemen, Company Size and Growth Company Auditor Switching on Mining Companies Listed In Indonesia Stock Exchange Period 2011-2014.

Sari, A. K., Deviyanti, D. R., \& Kusumawardani, A. (2018). Faktor - Faktor yang mempengaruhi voluntary auditor switching pada perusahaan yang terdaftar di BEI periode 2010-2015. Akuntabel 15 (1), 2018 17-28.

Sari, G. A. A. I. P., \& Astika I. B. P. (2018) Pengaruh Opini Going Concern, Financial Distress, dan Kepemilikan Institusional Pada Auditor Switching E-Jurnal Akuntansi Universitas Udayana Vol.23.2. Mei (2018): 898-926.

Soraya, E., \& Haridhi, M. (2017). Faktor-Faktor Yang Mempengaruhi Voluntary Auditor Switching (Studi Empiris pada Perusahaan Non Financing yang Terdaftar di Bursa Efek Indonesia tahun 2011-2015). Jurnal Ilmiah Mahasiswa Ekonomi Akuntansi (JIMEKA) Vol. 2, No. 1, (2017) Halaman 48-62.

Susanto, Y. K. (2018). Auditor Swiching
Management Turnover, Qualified Opinion, Audit Delay, Financial Distress, International. Journal of Business, Economics and Law, Vol. 15, Issue 5 (April) ISSN 2289-1552.

Undang-Undang Republik Indonesia Nomor 5 Tahun 2015 Tentang Akuntan Publik

Wea, A. N. S., \& Murdiawati, D. (2015). FaktorFaktor Yang Mempengaruhi Auditor Switching Secara Voluntary pada Perusahaan Manufaktur. Jurnal Bisnis dan Ekonomi (JBE), September 2015,Hal.154 170 Vol. 22, No.ISSN:14123126 STIE Perbanas Surabaya.

Widnyani, N. L. E. D., \& Muliartha, K. R. M. (2018). Pengaruh Opini Audit, Audit Fee, Reputasi KAP dan Ukuran Perusahaan Klien Terhadap Auditor Switching. E-Jurnal Akuntansi Universitas Udayana Vol.23.2. Mei (2018): 1119-1145. 